\title{
Manganese Determination by GFAAS in Feces and Fish Feed Slurries
}

\author{
Vanessa Rosa Loureiro, ${ }^{a}$ Mayra A. D. Saleh, ${ }^{a}$ Paula M. Moraes, ${ }^{a}$ Renato C. F. Neves, ${ }^{b}$ \\ Fabio A. Silva, ${ }^{b}$ Cilene C. F. Padilha ${ }^{c}$ and Pedro M. Padilha ${ }^{*, a}$
}

\author{
${ }^{a}$ Instituto de Biociências, Departamento de Química e Bioquímica, Universidade Estadual Paulista, CP 510 \\ 18618-000 Botucatu-SP, Brazil \\ ${ }^{b}$ Faculdade de Medicina Veterinária e Zootecnia, Departamento de Melhoramento e Nutrição Animal, \\ Universidade Estadual Paulista, CP 560 18618-000 Botucatu-SP, Brazil \\ ${ }^{c}$ Instituto de Biociências, Departamento de Física e Biofisica, Universidade Estadual Paulista, CP 510
} 18618-000 Botucatu-SP, Brazil

\begin{abstract}
Neste trabalho, um método simples, rápido e sensível, é proposto para determinação de manganês em amostras de fezes e rações de peixes por espectrometria de absorção atômica em forno de grafite (GFAAS) utilizando-se a introdução direta de suspensões das amostras no tubo de grafite. Os limites de detecção (LOD) e de quantificação (LOQ) calculados em relação a 20 leituras do branco das suspensões $(0,50 \% \mathrm{~m} / \mathrm{v}$ de fezes ou ração isentas de manganês) foram de 28 e $92 \mu \mathrm{g} \mathrm{kg}^{-1}$ para as suspensões padrão de fezes e de 34 e $110 \mu \mathrm{g}$ $\mathrm{kg}^{-1}$ para as suspensões padrão de ração. O método proposto foi aplicado em estudos de biodisponibilidade de manganês em diferentes amostras de rações de peixes e os resultados mostraram-se de acordo com os resultados obtidos utilizando-se amostras previamente mineralizadas por digestões ácidas em forno de microondas.
\end{abstract}

This paper presents a simple, fast and sensitive method to determine manganese in samples of feces and fish feed by graphite furnace atomic absorption spectrometry (GFAAS) by the direct introduction of slurries into the graphite tube. The limits of detection (LOD) and quantification (LOQ) calculated for 20 readings of the blank of the standard slurries $\left(0.50 \% \mathrm{~m} / \mathrm{v}\right.$ of feces or feed devoid of manganese) were 28 and $92 \mu \mathrm{g} \mathrm{kg} \mathrm{kg}^{-1}$ for the standard feces slurries and 34 and $110 \mathrm{~g} \mathrm{~kg}^{-1}$ for the standard feed slurries. The proposed method was applied in bioavailability studies of manganese in different fish feeds and their results proved compatible with those obtained for samples mineralized by acid digestion using microwave oven.

Keywords: slurries samples, GFAAS, chemical modifier, manganese determination

\section{Introduction}

Manganese is important for fish and is widely distributed in fish and animal tissue. The mitochondria have a greater concentration of manganese than cytoplasm or other cell organelles. Manganese is necessary for the normal functioning of brain and for proper lipid and carbohydrate metabolism. Manganese activates specific enzymes such as glycosyltransferase and non-specific enzymes such as kinases, transferases, hydrolases and decarboxylases. The activation of leucine aminopeptidase by manganese has been demonstrated in sole. An inadequate supply of

*e-mail: padilha@ibb.unesp.br manganese usually results in retardation of growth. The importance of manganese has been recognized in broodstock nutrition. The manganese content of the diet influences its level and that of other trace elements in gonads. ${ }^{1-5}$ The absence of manganese in a fish meal diet significantly influenced the mineral composition of common carp gonads. The eggs produced by broodstock of brook trout and rainbow trout fed fish meal diets lacking manganese contained only low levels of this trace metal and subsequently hatchability was poor. ${ }^{6-9}$

So, the development of new methodologies that allow the reliable quantification of the metallic nutrients such as manganese, present at low concentrations in feeds, becomes fundamental in fish nutrition studies. In this context, the 
determination of metallic analytes in slurries by graphite furnace atomic absorption spectrometry shows that it is a robust technique. It provides several advantages, such as, high sensitivity, detection limits extremely low, the use of small sample volumes, determination of a wide variety of trace elements, etc. Considering also that the atomizer can act as a chemical reactor, the possibility of making solid sampling presents some advantages over the conventional digestion procedures. Besides eliminating the stage of total previous decomposition of sample, it diminishes the sample preparation time, decreases the analyte losses for excessive manipulation or retention on insoluble products, reduces the possibility of sample contamination, and mainly minimizes the action of dangerous acids on the analyst. ${ }^{10-14}$

Taking into account theses acpects, this work describes the development of a method to determine manganese in slurries of fish feed and feces samples by GFAAS that eliminates the sample's mineralization step and allows for an estimate of its bioavailability.

\section{Experimental}

\section{Reagents, standard solutions and samples}

High purity deionized water $\left(18.2 \mathrm{M} \Omega \mathrm{cm}^{-1}\right)$ obtained with an Elga Ionic system (PURELAB Option, USA), pure nitric acid (Merck P.A.), hydrogen peroxide (Merck) and Triton X-100 (Merck) were used throughout this work. The solution containing tungsten, which was employed to coat the inside of the graphite tube and used as a permanent modifier, was prepared by diluting a stock solution containing $1000 \mathrm{mg} \mathrm{L}^{-1}$ of sodium tungstate (Merck) with ultrapure water. The Pd(II) solution, also employed as a chemical modifier, was made in the same way, utilizing palladium nitrate (Merck) instead.

Stock solutions of the analytes were prepared from reagents of spectroscopic purity (Johnson \& Matthey, Royston, Hertfordshire, UK). The remaining solutions utilized, including the concentrated acid solutions used for mineralizing the samples, were analytical grade. All bottles for storing samples and standard solutions, glassware and containers of the atomic absorption spectrometer's autosampler were immersed in $10 \% \mathrm{v} / \mathrm{v}$ nitric acid for $24 \mathrm{~h}$, rinsed with ultrapure water and dried before being used.

The fish feces and feed samples were dried at $50{ }^{\circ} \mathrm{C}$ in an oven with forced air circulation for $48 \mathrm{~h}$ and then cryogenically ground. A mass of approximately $1.0 \mathrm{~g}$ of the sample, together with a magnetic bar, were put into a polycarbonate flask, which was then closed and immersed in liquid nitrogen. The impact between the sample and the magnetic bar, subjected to an oscillating magnetic field (20 impacts $\mathrm{s}^{-1}$ ), pulverized the sample. The sample grinding program consisted of an initial stage of $2 \mathrm{~min}$ of prefreezing, $1 \mathrm{~min}$ of pulverization, and again $1 \mathrm{~min}$ of freezing, followed by a second stage comprising two cycles of two pulverization and freezing stages, making a total of $8 \mathrm{~min}$. This procedure yielded particles with a granulometry of less than $60 \mu \mathrm{m} .^{15,16}$

A portion of the samples was also mineralized in a microwave oven, as follows. Portions of $50 \mathrm{mg}$ of cryogenically ground samples were transferred directly to the Teflon flasks of the microwave oven, and $2.5 \mathrm{~mL}$ of pure nitric acid $14 \mathrm{~mol} \mathrm{~L}^{-1}$ plus $0.50 \mathrm{~mL}$ of hydrogen peroxide $30 \% \mathrm{~m} / \mathrm{m}$ were added. Thereafter, the following power/timer program was run: step $1,300 \mathrm{~W} / 3 \mathrm{~min}$; step 2, $0 \mathrm{~W} / 2 \mathrm{~min}$; step 3, $450 \mathrm{~W} / 5 \mathrm{~min}$, step 4, $550 \mathrm{~W} / 5 \mathrm{~min}$; step 5, $650 \mathrm{~W} / 5 \mathrm{~min}$; step 6 (ventilation), $0 \mathrm{~W} / 5 \mathrm{~min}^{16}$ After cooling, the resulting acid digestates were diluted to $50 \mathrm{~mL}$ with ultrapure water.

\section{Biological material for preparing the standard slurries}

A feed devoid of some metal nutrients was prepared (in the case, devoid of calcium, iron, cobalt, copper, manganese, selenium and zinc). This feed was formulated with dehydrated starch, albumin and premix potassium and magnesium oxides. A lot of Nile Tilapia, Oreochromis niloticus juveniles, was fed with this feed in separate aquarium. The collected excrements were similar to the diets and contained all the metal nutrients. After the collection, the feces were treated as described in the previous item, however, the cryogenic milling was performed after washing exhaustingly with pure nitric acid $0.10 \mathrm{~mol} \mathrm{~L}^{-1}$, ultrapure water and drying was applied as already mentioned.

\section{Slurry sample preparation}

After cryogenic grinding, $5 \mathrm{mg}$ of the biological material samples (fish feed or feces) were transferred directly to the containers of the spectrometer autosampler, to which $5 \mu \mathrm{L}$ of pure nitric acid $14 \mathrm{~mol} \mathrm{~L}^{-1}, 50 \mu \mathrm{L}$ of Triton X-100 at $1 \% \mathrm{v} / \mathrm{v}, 100 \mu \mathrm{L}$ of $1000 \mathrm{mg} \mathrm{L}^{-1}$ of $\mathrm{Pd}(\mathrm{II})$ solution and $845 \mu \mathrm{L}$ of ultrapure water were added. The biological material slurry samples were then sonicated for $40 \mathrm{~s}$ directly in the autosampler containers.

\section{Apparatus}

A Provecto Analítica model DGT 100 plus microwave oven (Campinas, Brazil) was used to mineralize the samples. 
For the manganese determinations, a Shimadzu model AA-6800 atomic absorption spectrometer was used, equipped with a background absorption corrector by selfreversal method (SR) system, and a pyrolytic graphite tube with integrated platform and automatic ASC-6100 sampler. A Shimadzu hollow cathode manganese lamp operated with a $10 \mathrm{~mA}$ current was also used. The wavelength applied was $279.5 \mathrm{~nm}$ and the spectral resolution was $0.5 \mathrm{~nm}$. Argon was used as inert gas at a constant flow of $1 \mathrm{~L} \mathrm{~min}^{-1}$ throughout the heating program, except during the atomization step, when the gas flow was interrupted. The absorbance signals were measured in peak area.

The samples were cryogenically ground in a Spex Freezer model Mill 6750 cryogenic mill. The slurries of fish feces and feeds were sonicated in a Unique ultrasonic cell disruptor.

Preparation of the graphite tube coated internally with tungsten

The inner walls of the pyrolytic graphite tubes with integrated platform used for determining manganese were coated with tungsten. This was made by injecting aliquots of $25 \mu \mathrm{L}$ of a solution containing $1000 \mathrm{mg} \mathrm{L}^{-1}$ of the sodium tungstate modifier into the atomizer, which was then submitted to the stages of the heating program described in Table 1. This procedure was repeated twenty times. After applying to the heating program described in Table 1, the W(VI) deposited on the graphite tube inner wall, forming a layer of tungsten carbide, acted as a chemical modifier. ${ }^{17}$ In this case, the mass of tungsten deposited was $500 \mu \mathrm{g}$. Using this treatment it was possible to use a graphite tube for up to 572 firings.

Table 1. Heating program used for coating the inner wall of the graphite tube with tungsten carbide

\begin{tabular}{lcccc}
\hline Step & Temperature $/{ }^{\circ} \mathrm{C}$ & \multicolumn{2}{c}{ Stage } & Argon flow \\
& & Ramp/s & Hold $/ \mathrm{s}$ & $\left(\mathrm{L} \mathrm{min}^{-1}\right)$ \\
\hline 1 & 110 & 5 & 25 & 0.3 \\
2 & 150 & 10 & 25 & 0.3 \\
3 & 600 & 10 & 20 & 0.3 \\
4 & 1200 & 10 & 20 & 0.3 \\
5 & 2000 & 3 & 2 & 0.3 \\
6 & 2200 & 0 & 5 & 0.3 \\
\hline
\end{tabular}

Initial temperature of furnace, $95^{\circ} \mathrm{C}$

\section{Standard slurries preparation}

Analytical curves were prepared using fish feed and feces slurries containing $1,2,4,5$ and $10 \mu \mathrm{g} \mathrm{L}^{-1}$ of manganese with the absorbance readings performed by
GFAAS. These standard slurries were prepared under the same conditions as those used for preparing the slurries of feed and feces samples, using however, $5 \mathrm{mg}$ of standard samples of biological material devoid of manganese. Thus, to prepare the analytical curves, volumes of $4,8,16,20$ and $40 \mu \mathrm{L}$ of standard solutions containing $250 \mu \mathrm{g} \mathrm{L}^{-1}$ of manganese were transferred to the spectrometer autosampler containers before the final volume adjustment to $1000 \mu \mathrm{L}$ with ultrapure water, so that the manganese concentrations in the standard slurries were within the range of 1 to $10 \mu \mathrm{g} \mathrm{L}^{-1}$. The standard solutions containing 1 to $10 \mu \mathrm{g} \mathrm{L}^{-1}$ of manganese in $0.5 \% \mathrm{v} / \mathrm{v}$ pure $\mathrm{HNO}_{3}$, were also used for preparing analytical solutions used for manganese determinations in samples of feces and feeds mineralized by microwave-assisted acid digestion.

\section{Analytical procedure}

After the sonication step of the sample in slurries and/ or standard slurries directly in the autosampler containers, a volume of $10 \mu \mathrm{L}$ of standard or sample was introduced into the graphite tube (coated internally with tungsten carbide), using the autosampler micropipette. Each measurement was repeated five times. Table 2 describes the heating program of the graphite tube, which was optimized to determine manganese.

Table 2. Graphite tube heating program optimized for the determination of manganese in slurries of fish feces and feed samples

\begin{tabular}{lcccc}
\hline \multirow{2}{*}{ Step } & Temperature $/{ }^{\circ} \mathrm{C}$ & \multicolumn{2}{c}{ Stage } & \multirow{2}{*}{$\begin{array}{c}\text { Argon flow } \\
\left.(\mathrm{L} \mathrm{min})^{-1}\right)\end{array}$} \\
\hline Drying & 150 & 10 & 0 & 1 \\
Drying & 250 & 10 & 5 & 1 \\
Pyrolysis & 1600 & 10 & 5 & 1 \\
Pyrolysis & 1600 & 5 & 20 & 1 \\
Atomization & 2400 & 1 & 3 & 0 \\
Cleanup & 2800 & 5 & 0 & 1 \\
\hline
\end{tabular}

Initial temperature of furnace, $95^{\circ} \mathrm{C}$

\section{Results and Discussion}

\section{Optimization of the instrumental conditions}

The accuracy and precision of the analytical results in the determination of metals by GFAAS using slurries depends on the optimization of the temperatures of pyrolysis and atomization of the analyte. Therefore, pyrolysis and atomization curves were drawn to determine these parameters for the manganese in standard slurries of fish feed and feces containing $10 \mu \mathrm{g}$ $\mathrm{L}^{-1}$ of $\mathrm{Mn}, 10 \mathrm{mg} \mathrm{L}^{-1}$ of $\mathrm{Pd}(\mathrm{II})$, using the graphite tube coated internally with tungsten carbide and using the 
samples preparation conditions previously described. The Figure 1 (curves a, b, e and f) illustrate the influence of the pyrolysis and atomization temperatures on the absorbance signals for manganese in the standard slurries of biological materials. The pyrolysis temperature of $1600{ }^{\circ} \mathrm{C}$ was selected because, as Figure 1 (curves a and b) indicates, the absorbance signals obtained for the manganese remained constant in the range 1400 $1600{ }^{\circ} \mathrm{C}$, declining rapidly after reaching $1600{ }^{\circ} \mathrm{C}$. As for the atomization temperature (Figure 1, curves e and $\mathrm{f}$ ), the absorbance signals obtained for the manganese were constant from $2400^{\circ} \mathrm{C}$ up for both standard slurries, so the atomization temperature of $2400{ }^{\circ} \mathrm{C}$ was selected for all the remaining experiments. Figure 2 (graphics a and $b$ ) depicts the analyte absorbance (AA) and background absorbance (BG) signals for the standard slurries of the biological materials. Both Figures show a relatively low background absorbance, indicating the efficiency of Pd and tungsten carbide modifiers in the stage of pyrolysis. The biological materials studied here contained around $0.12 \%$ of magnesium and this element in the matrix may help in the thermal stabilization of manganese, according to the literature. It was already shown for chromium and manganese that the presence of magnesium in the matrix favored the thermal stabilization of this elements. ${ }^{16,18,19}$

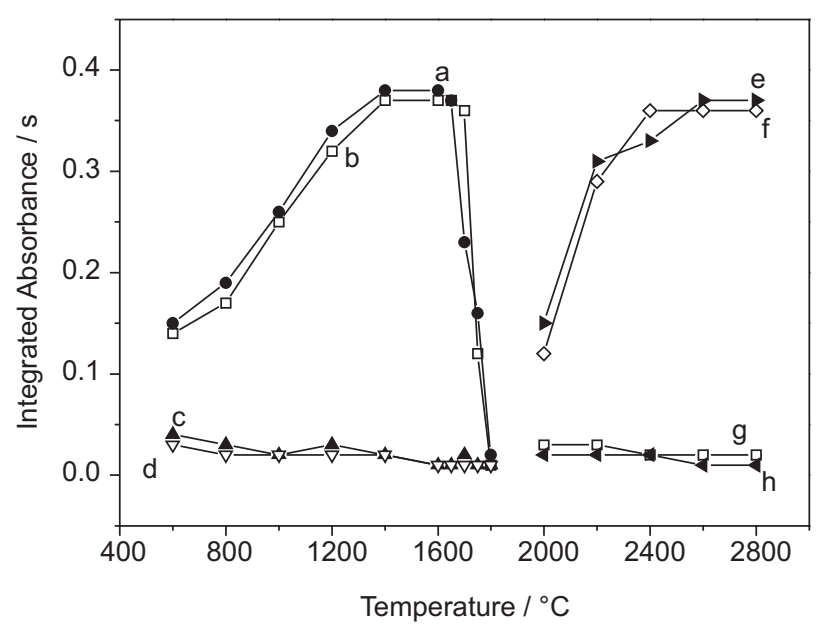

Figure 1. Pyrolysis and atomization temperature curves for standard samples containing $10 \mu \mathrm{g} \mathrm{L}^{-1}$ of Mn. Pyrolysis curves (Atomization temperature, $2400^{\circ} \mathrm{C}$ ): a-Standard slurry feces; b-Standard slurry feed; c-Standard slurry feces (BG); d-Standard slurry feed (BG); Atomization Curves (Pyrolysis temperature, $1600^{\circ} \mathrm{C}$ ): e-Standard slurry feces; f-Standard slurry feed; g-Standard slurry feces (BG); h-Standard slurry feed (BG).

\section{Determination of the optimal sonication time of the slurry} samples

Ultrasonic shaking to analyze slurries of solid materials ensures good homogenization of the sample,
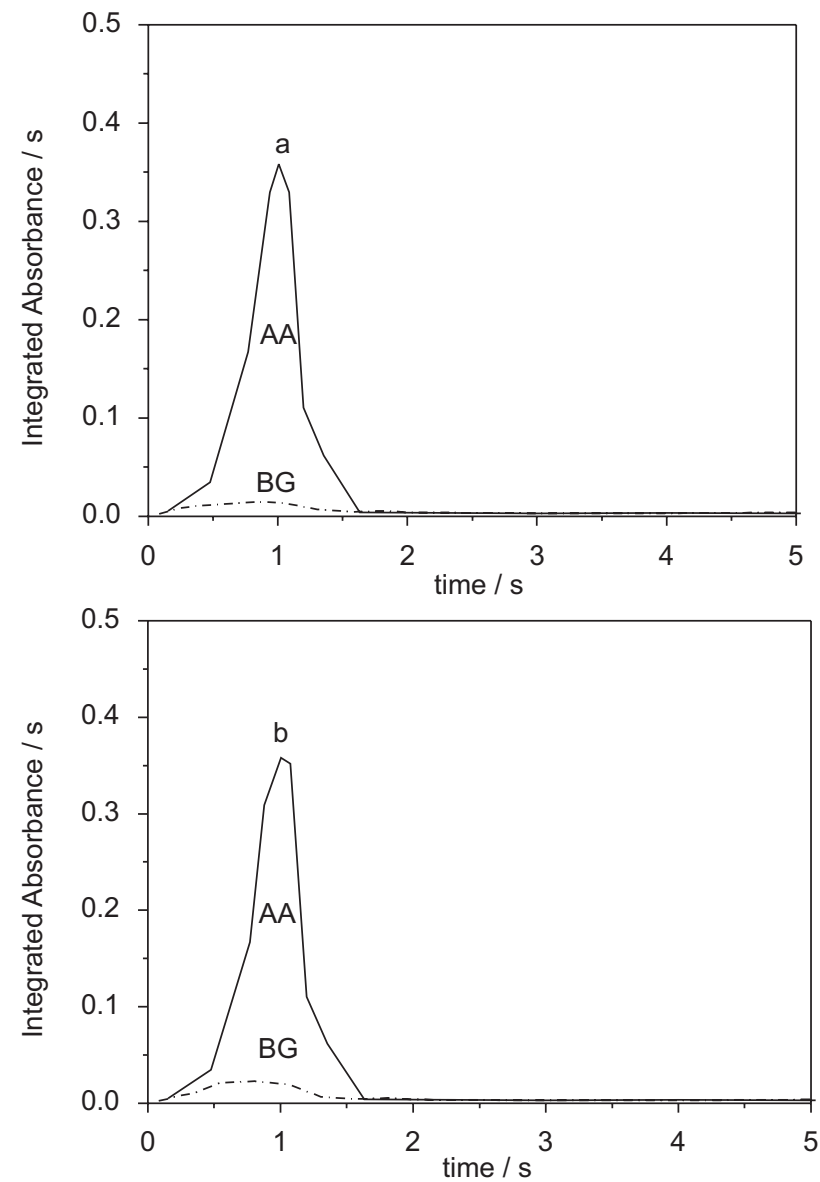

Figure 2. Transient atomic absorption (AA) and background (BG) signals in the atomization of manganese in standard slurries samples containing $10 \mu \mathrm{g} \mathrm{L} \mathrm{L}^{-1}$ of Mn. Graphic a) Standard slurry feces; b) Standard slurry feed.

allowing for better reproducibility between measurements. Thus, the sample ultrasonication time was evaluated in the interval of 10 to $60 \mathrm{~s}$ of agitation. Figure 3 depicts the influence of the sonication time of samples on the absorbance signals obtained for Mn and also the relative deviation standard regarding (RSD) to each ultrasonication time. An analysis of this figure indicates that the absorbance signals remain constant starting from $20 \mathrm{~s}$ of sonication. The sonication time of $40 \mathrm{~s}$ was considered optimal considering the good absorbance signal obtained but also the RSD among the measurements was relatively low $(1.8 \%))^{15,16}$

\section{Analytical calibration curves}

Based on the parameters of pyrolysis and atomization temperatures and the profile of the optimized atomic absorption signal and matrix-matched standards analytical curves were plotted using standard slurries of fish feces and feed containing $\mathrm{Mn}$ in the 


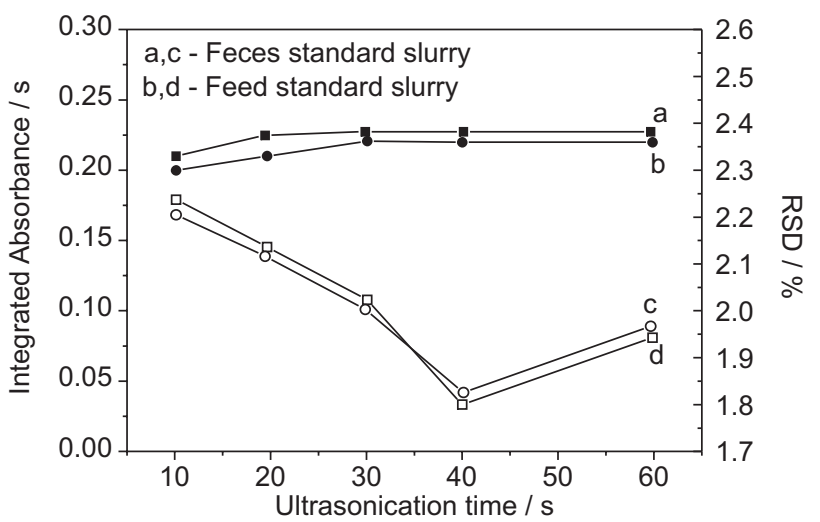

Figure 3. Influence of ultrasonication time on the manganese absorbance signal and on relative standard deviation (RSD) in the standard slurries on fish feces and feed containing $10 \mu \mathrm{g} \mathrm{L}^{-1}$ of Mn. Curves a,b Ultrasonification time (s) versus Integrated absorbance (s); Curves c, d Ultrasonification time (s) versus RSD (\%).

concentration range from 1 to $10 \mu \mathrm{g} \mathrm{L}^{-1}$ (as described before in Standard slurries preparation). Figure 4 depicts the analytical curves obtained and their respective straight-line equations. A comparison of the analytical curve prepared with fish feces and the one prepared with fish feed indicates that their slopes do not show significant differences $(\mathrm{k}=0.0381$ for feces, curve a and $\mathrm{k}=0.0361$ for feed, curve b). Both analytical curves show absorbance values approximately $5-10 \%$ lower than the values of the analytical curve obtained from the standard solutions prepared in the range of 1 to $10 \mu \mathrm{g} \mathrm{L}^{-1}$ of $\mathrm{Mn}$ in $10 \% \mathrm{v} / \mathrm{v}$ pure $\mathrm{HNO}_{3}$ (straight line equation: $\mathrm{A}=0.0031+0.0191 \mathrm{C}_{\mathrm{Mn}}$ ). However, the slopes of these straight lines obtained for the standard slurries were about 2 -fold greater, attesting to the efficiency of the pyrolysis and atomization steps. An accumulation of carbonaceous residues inside the

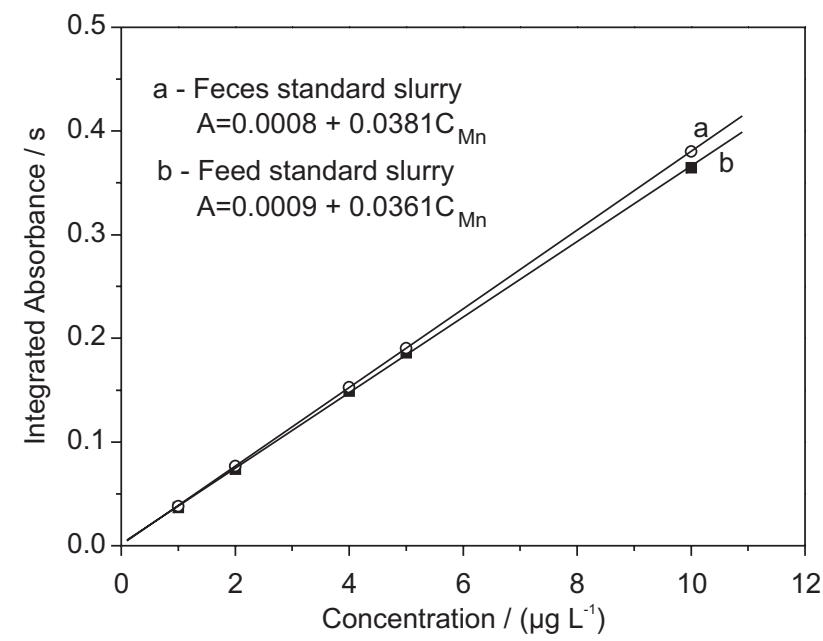

Figure 4. Analytical curve obtained from standard slurry of fish feces and feed contained $1,2,4,5$ and $10 \mu \mathrm{g} \mathrm{L} \mathrm{L}^{-1}$ of $\mathrm{Mn}$. graphite tube, causing partial obstruction of the radiation from the hollow cathode lamp, can impair absorbance measurements. ${ }^{18}$ Nevertheless, the low background (BG) signals obtained in the manganese optimization stage of the proposed procedure indicate that the carbon residue left behind by the pyrolysis state did not impair the absorbance measurements. The characteristic masses calculated were 23.15, 24.12 and $20.92 \mathrm{pg}$ for the standard slurry feces, standard slurry feed and Mn standard solution, respectively. ${ }^{20,21}$ The detection limit (LOD) and the quantification limit (LOQ) were calculated based on the standard deviation of 20 readings obtained for the blanks of the standard slurries and the slopes of the analytical curves ( $\mathrm{LOD}=$ $3 \sigma /$ slope and $\mathrm{LOQ}=10 \sigma /$ slope $)$. Their values were 28 and $92 \mu \mathrm{g} \mathrm{kg}^{-1}$ of Mn for the standard slurry feces and 34 and $110 \mu \mathrm{g} \mathrm{kg}^{-1}$ of Mn for the standard slurry feeds, respectively. ${ }^{20,21}$ These results demonstrate that the proposed method offers an acceptable level of precision. The lifetime of the graphite tube was equivalent to 572 firings. Experiments made using only Pd as modifier led to a graphite tube lifetime of 180 firings. Then, with tungsten carbide deposited on the graphite tube inner wall and introducing Pd together with the sample, it was possible to run a pyrolysis temperature of $1600{ }^{\circ} \mathrm{C}$ and the graphite tube lifetime was improved. Considering the complexity of the biological matrices, the tube lifetime with the proposed method is acceptable when compared to other methods described in the literature. ${ }^{16,18,19}$ After optimization, the accuracy of proposed method for the determination of manganese were investigated in slurries of four feed samples enriched with this micronutrient used in the fish diet (Table 3). The accuracy of the results obtained were checked adopting a mineralization of the samples in a microwave oven and they were not statistically different at a $95 \%$ confidence level (paired $t$-test).

\section{Application of the proposed method}

After the optimization, the applicability of the newly developed method was tested in the determination of Mn

Table 3. Mean contents and standard derivations $(\mathrm{n}=5$ ) obtained for manganese in enriched feed samples using the developed procedure with slurry sampling and microwave-assisted acid digestion procedure

\begin{tabular}{lcc}
\hline Samples feed & $\begin{array}{c}\text { Slurry sampling } \\
\left(\mathrm{mg} \mathrm{kg}^{-1}\right)\end{array}$ & $\begin{array}{c}\text { Microwave-assisted } \\
\text { acid digestion }\left(\mathrm{mg} \mathrm{kg}^{-1}\right)\end{array}$ \\
\hline Yeast & $10.98 \pm 0.22$ & $10.11 \pm 0.26$ \\
Corn & $10.10 \pm 0.31$ & $8.97 \pm 0.28$ \\
Soybean bran & $8.87 \pm 0.28$ & $8.11 \pm 0.21$ \\
Rice bran & $7.95 \pm 0.14$ & $6.96 \pm 0.15$ \\
\hline
\end{tabular}


Table 4. Coefficient of bioavailability of manganese of Nile tilapia juveniles fed with different food supplements

\begin{tabular}{|c|c|c|c|c|}
\hline & \multicolumn{4}{|c|}{ Feed samples } \\
\hline & Yeast & Corn & Soybean bran & Rice bran \\
\hline Coefficient of bioavailability (\%) & $75 \pm 2^{*} \quad 73 \pm 2^{\#}$ & $69 \pm 1^{*} \quad 67 \pm 1^{\#}$ & $73 \pm 1^{*} \quad 71 \pm 1^{\#}$ & $67 \pm 1^{*} \quad 65 \pm 1^{\#}$ \\
\hline
\end{tabular}

*Calculation based on the $\%$ Mn determined by proposed method; \# Calculation based on the $\%$ Mn determined by GFAAS after mineralization of the feed and feces samples in a microwave oven

in four samples of feed containing different manganese supplements used in the diet of Nile tilapia juveniles and in samples of feces from these fish. Then, based on the values of the percentage of $\mathrm{Cr}_{2} \mathrm{O}_{3}$ and of manganese determinations on the feeds, a calculation was made to estimate the coefficient of bioavailability of this micronutrient, using equation $1.22-24$

$$
\mathrm{Da}=100-100\left[\left(\frac{\% \mathrm{Cr}_{2} \mathrm{O}_{3} \mathrm{r}}{\% \mathrm{Cr}_{2} \mathrm{O}_{3} \mathrm{f}}\right) \times\left(\frac{\% \mathrm{Mn} \mathrm{f}}{\% \mathrm{Mn} \mathrm{r}}\right)\right]
$$

where:

$\mathrm{Da}=$ Apparent digestibility

$\% \mathrm{Cr}_{2} \mathrm{O}_{3 \mathrm{r}}=$ Percentage of chromic oxide in the feed

$\% \mathrm{Cr}_{2} \mathrm{O}_{3 \mathrm{f}}=$ Percentage of chromic oxide in the feces

$\% \mathrm{Mn}_{\mathrm{r}}=$ Percentage of manganese in the feed

$\% \mathrm{Mn}_{\mathrm{f}}=$ Percentage of manganese in the feces

Table 4 lists the values of the coefficients of bioavailability calculated based on the manganese determinations by the proposed method and by GFAAS after mineralization of the feed samples in a microwave oven. A comparison of the values of the coefficient of bioavailability of manganese present in the four types of feed used in the diet of Nile tilapia juveniles (Table 4) reveals that the values found based on the determinations using the proposed method are congruent with those obtained by the GFAAS method after mineralization of the feed and feces samples in a microwave oven. The GFAAS method is normally used in fish nutrition mineral bioavailability studies; ${ }^{22-26}$ hence, our results attest to the applicability of the proposed method in such studies.

\section{Conclusions}

The proposed method for quantifying of manganese using samples of fish feed and feces in the slurry form to estimate the apparent bioavailability of this micronutrient in feeds used in fish nutrition yielded results equivalent to those obtained with the GFAAS quantification method, whose initial step involves the mineralization of samples in a microwave oven. The main advantage of the proposed method is that it does not generate toxic residues, which can be harmful to the analyst's health and contaminate the environment. Moreover, since this new method does not require mineralizing the samples, it considerably reduces the time spent on analytical determinations in fish nutrition analyses. In addition it offers limits of detection (LOD) and of quantification (LOQ) in the order of 28 and $92 \mu \mathrm{g} \mathrm{kg}^{-1}$, respectively, using only $10 \mu \mathrm{L}$ of slurry samples for each analytical determination. The comparison of values of the detection limits calculated by the proposed method with that obtained by the GFAAS $\left(0.12 \mu \mathrm{g} \mathrm{L}^{-1}\right)$ using aqueous standard solutions, shows acceptable sensitivity to the proposed method.

\section{Acknowledgments}

The authors gratefully acknowledge the financial support of FAPESP (Brazil) (Processes 03/13362-6, 06/ 51362-6, 06/51556-5 and 06/57149-2) and CAPES for fellowships granted to Fabio Arlindo Silva.

\section{References}

1. Clark, J.; Macdonald, N. L.; Stark, J. R.; Aquaculture 1987, $61,231$.

2. Ogino, C.; Yang, G. Y.; Nippon Suisan Gakkaishi 1980, 46, 455.

3. Ishac, M. M.; Dollar, A. M.; Hydrobiology 1968, 31, 572.

4. Satoh, S.; Yamamoto, H.; Takeuchi, T.; Watanabe, T.; Hydrobiology 1983, 49, 425.

5. Knox, D.; Cowey, C. B.; Adron, J. W.; J. Nut. 1981, 46, 495.

6. Watanabe, T.; Satoh, S.; Takeuchi, T.; Aquaculture 1997, 151, 185.

7. Gatlin, I. D. M.; Wilson, R. P.; Aquaculture 1984, 41, 85.

8. Satoh, S.; Takeuchi, T.; Watanabe, T.; Nippon Suisan Gakkaishi 1987, 53, 825 .

9. Takeuchi, T.; Watanabe, T.; Ogino, C.; Saito, M.; Nishimura, K.; Nose, T.; Nippon Suisan Gakkaishi 1981, 47, 645.

10. Volynsky, A.; Spectrochim. Acta, Part B 1998, 53, 139.

11. Tsalev, D. L.; Slaveykova, V. I.; Lampugnani, L.; D’ulivo, A.; Georgieva, R.; Spectrochim. Acta, Part B 2000, 55, 473.

12. Shiue, M. Y.; Mierzwa, J.; Yang, M. H. J.; J. Anal. At. Spectrom. 2001, 16, 1172.

13. Bendicho C.; Loos-Vollebregt, M. T. C.; J. Anal. At. Spectrom. 1991, 6, 353. 
14. Liang, Y. Z.; Li, M.; Rao, Z.; Anal. Sci. 1996, 12, 633.

15. Millerihli, N. I.; Fresenius J. Anal. Chem. 1993, 345, 489.

16. Rosa, C. R.; Moraes, M.; Gomes Neto, J. A.; Nóbrega, J. A.; Nogueira, A. R. A.; Food Chem. 2002, 79, 523.

17. Lima, E. C.; Krug, F. J.; Jackson, K. W.; Spectrochim. Acta, Part B 1998, 53, 1791.

18. Aleixo, P. C.; Nóbrega, J. A.; Santos, D. J.; Muller, R. C. S.; Quim. Nova 2000, 23, 310.

19. Minami, H.; Yada, M.; Yoshida, T.; Zhang, T. Q.; Inoue, S.; Atsuya, I.; Anal. Sci. 2004, 20, 455.

20. Beaty, R. B.; Kerber, J. D. Concepts, instrumentation and techniques in atomic absorption spectrometry. Norwalk: The Perkin Elmer Corporation, 1993.

21. Currie, L. A.; Anal. Chim. Acta 1999, 391, 105.
22. Sa, M. V. D. E.; Pezzato, L. E.; Barros, M. M.; Padilha, P. M.; Aquaculture 2004, 238, 385.

23. Sa, M. V. D. E.; Pezzato, L. E.; Barros, M. M.; Padilha, P. M.; Aquaculture Nutrition 2005, 11, 273.

24. Sa, M. V. D. E.; Pezzato, L. E.; Barros, M. M.; Padilha, P. M.; J. World Aquacult. Soc. 2005, 36, 380.

25. Furuya, W. M.; Pezzato, L. E.; Pezzato, C. A.; Barros, M. M.; Miranda, E. C.; Rev. Bras. Zootec. 2001, 30, 1143.

26. Pezzato, L. E.; Barros, M. M.; Miranda, E. C.; Pinto, L. G. Q.; Furuya, W. M.; Pezzato, A. C.; Rev. Bras. Zootec. 2002, 31, 1595 .

Received: November 23, 2006

Web Release Date: October 2, 2007

FAPESP helped in meeting the publication costs of this article. 